\title{
Are Participants in Bond Market Concerned about the Quality of Information Disclosure: Evidence from Chinese Listed Companies
}

\author{
Huan Luo', Changhai Yu², Ran Su${ }^{1}$ \\ ${ }^{1}$ School of Economics and Business Administration, Beijing Normal University, Beijing, China \\ ${ }^{2}$ NCS Testing Technology Co., Ltd., Beijing, China \\ Email: luohuan@bnu.edu.cn, bnuych@126.com, suran87@126.com
}

Received 19 July 2014; revised 12 August 2014; accepted 16 September 2014

Copyright (C) 2014 by authors and Scientific Research Publishing Inc.

This work is licensed under the Creative Commons Attribution International License (CC BY). http://creativecommons.org/licenses/by/4.0/

cc) (i) 0 pen Access

\begin{abstract}
High quality of information disclosure can reduce the information asymmetry, which is very important to the effective operation of the capital market. This article studies whether participants in bond market are concerned about the quality of information disclosure based on a sample of listed companies in China's bond market from 2007 to 2013. We find that there is no significant relationship between information disclosure quality and credit rating, indicating the credit rating agencies are not concerned about information disclosure quality. However, we find information disclosure quality can significantly reduce the bond financing cost, which indicates that bond investors are concerned about information disclosure quality.
\end{abstract}

Keywords

Information Disclosure Quality, China's Bond Market, Credit Rating, Bond Financing Cost

\section{Introduction}

Although the bond market develops rapidly in recent years, China's bond market is still far behind the stock market (Bottelier, 2003) [1]. As a comprehensive measure of corporate credit risk, the quality of corporate disclosure should be important for corporate credit rating. However, due to the ineffectiveness of China's bond market, credit ratings have always been questioned. There is no conclusion about whether the information disclosure quality would affect the level of bond credit rating and whether credit rating agencies are concerned 
about the disclosure quality. Moreover, there is also no research on whether bond investors are concerned about the information disclosure quality.

High quality of information disclosure can help to solve the problem of asymmetric information and reduce the moral and speculation risk. This plays a very important role in protecting the investors' interests and promoting the development of capital market. However, as China's bond market development is relatively lagged, Chinese academics tend to study stock market rather than bond market. Whether improving the quality of information disclosure could reduce the bond financing cost is inconclusive. This article explores whether the China's bond market participants are concerned about the information disclosure quality, trying to make up for the lack of related research and making some policy suggestions for the development of China's bond market.

\section{Literature Review}

The most two important theories studying information disclosure are the efficient market theory and signaling theory. Both of the two theories agree that the disclosure of information plays a very important role in the capital market. About the relationship between the information disclosure quality and credit rating, there are some theories and empirical literature show that the high information disclosure quality will bring a high credit rating. Currently there's no direct literature in china studying such relationship, related researches focus on information disclosure status of the bond market, and whether credit rating could reflect the corporate's financial condition. There's also no direct literature studying the relationship between the information disclosure quality and bond financing cost. Relevant research focuses on the relationship between information disclosure quality and the cost of equity financing, and relationship between corporate's financial condition and bond financing cost.

Information disclosure plays a very important role in corporate governance. For internal governance, the information disclosure quality may reflect the level of management control; for external governance, improving the disclosure quality helps to protect investors and maintain a healthy development of the market. High quality of information disclosure can solve the information asymmetry problem to a certain extent, which is very important to the effective operation of the capital market. Bond credit rating, as a comprehensive measure of corporate credit risk, should consider a lot of factors such as the bond issuing company's economic environment, industry characteristics, competitive situation, management capabilities and financial conditions, etc. That's why the corporate disclosed information should be an important source for bond credit rating. Barry, Brown (1985) [2], Coles and Loewenstein (1988) [3], and Clarkson et al. (1996) [4] find that high information disclosure quality can reduce the chance of mistake when investors estimating corporate credit risk. Heflin et al. (2011) [5] did an empirical research with the U.S. bond market data to test the relationship between information disclosure quality and credit rating, they found that the higher quality of information disclosed in the annual report, the higher credit rating.

Improving the quality of information disclosure will help to reduce the capital cost. The first reason is high information disclosure quality will increase the corporate stock and bond liquidity (Diamond and Verrecchia, 1991) [6]. The Second reason is the high information disclosure quality is good for reducing the investors' estimating risk of future earnings (Handa and Linn, 1993) [7]. Heflin et al. (2011) [5] did an empirical research on the relationship between the information disclosure quality and credit rating with the U.S. bond market data, they found the higher quality of information disclosed in the annual report, the lower the bond financing cost.

\section{Hypothesis}

In recent years, as the China's bond market continues to mature and develop, the bond market regulation is more stringent and the investors become more rational, the China's credit rating system is gradually improving. Several Chinese major rating agencies started to cooperate with foreign rating authorities, such as Moody's acquisition of China Chengxin Credit Rating Group with absolute control in 2006. Also in 2006, Xinhua Finance (controlled by U.S.) acquired Shanghai Far East. In 2007, Standard \& Poor's cooperated with Shanghai New Century, the two sides also took joint venture into consideration. By cooperating with foreign rating agency authorities, China's credit rating agencies improved their rating techniques and reputation. Zhu (2013) [8] found that credit ratings after 2005 reflect differences on corporates' profitability, debt levels, scale factors, and ownership structures. Moreover, the signal theory also works in China's bond market. The quality of information disclosure as another signal that reflects corporate governance and future risk should be able to get the investors' recognition. 
Due to the information asymmetry, the quality of accounting information and disclosure is often seen as the signal of corporate condition and performance. Wiedman (2000) [9] studied the relationship between voluntary disclosures and issuing stock and found voluntary disclosure can reduce information asymmetry between investors and companies. Barry and Brown (1985) [2], Coles and Loewenstein (1988) [3] and Clarkson et al. (1996) [4] found high information disclosure quality can reduce mistake when investors estimating credit risk. Heflin et al. (2011) [5] found the higher information quality corporate disclose, the higher credit rating it will get.

Based on above analysis, we believe that credit rating agencies in the bond market are concerned about the information disclosure quality. Therefore, we come up with Hypotheses 1.

Hypotheses 1: The corporate information disclosure quality has a positive impact on the credit rating, the higher information disclosure quality, the higher credit rating.

As an important measure of corporate credit risk indicators, credit ratings affect bond financing cost. Although the independence and effectiveness of China's credit rating agencies has been questioned, but recent studies have found that the China's bond market corporate credit rating would significantly affect the corporate's bond financing cost. As we've discussed earlier, if information disclosure quality can significantly affect credit rating, then information disclosure quality should also affect the company's bond financing cost indirectly.

Apart from the intermediary role of credit rating, the information disclosure quality will directly affect the corporate's financing cost from the following aspects: firstly, improve the quality of information disclosure will help increase the liquidity of corporate stocks and bonds, thereby reducing the capital cost (Diamond and Verrecchia, 1991) [6]; Secondly, improve the quality of information disclosure will help reduce the investors' estimating risk of future earnings, thereby reducing the capital cost (Handa and Linn, 1993) [7].

Based on above analysis, we believe that investors in the bond market are concerned about the quality of information disclosure. Therefore, we come up with Hypotheses 2.

Hypotheses 2: The corporate information disclosure quality has a negative impact on corporate bond financing cost, the higher information disclosure quality, the lower bond financing cost.

\section{Research Design}

\subsection{Models and Variables}

Since rating agencies sequence the corporate credit ratings in order, we use sequencing logic model (Ordered Logit) in our empirical analysis. Based on previous research on credit rating (Elton et al., 2004; Perraudin and Taylor, 2004) [10] [11], our model to test Hypotheses 1 is as follows:

$$
\begin{aligned}
\text { Credit }= & a_{0}+a_{1} \text { DisQuality }+a_{2} \text { AccQuality }+a_{3} \text { Roe }+a_{4} \text { Size }+a_{5} \text { Lev }+a_{6} \text { CFO }+a_{7} \text { GDPgrow } \\
& +a_{8} \text { State }+a_{9} \text { Duration }+a_{10} \text { Guarantee }+a_{11} \text { Type }+\sum a_{i} \text { Inds } s_{i}+e
\end{aligned}
$$

When credit rating agencies are rating a corporate's credit, they also give a rating of the bond issued by the corporate. But in the practice of credit rating in China, the rating standards of short-term financing bond are different from other types of bond, thus research often uses the corporate credit rating directly, namely the credit rating for issuing corporates. This article also directly uses the corporate credit rating, and in order to make the results more robust, we also use the bond rating ${ }^{1}$ as the robustness test by eliminating the sample of short-term financing bond.

Credit means the corporate credit rating, because the sample of this article is listed company, the rating data does not cover all areas. The corporate credit rating in this article has 6 grades, which are AAA, AA+, AA, AA-, $\mathrm{A}+$ and $\mathrm{A}$. AAA is the best grade. In order to do regression analysis, we assign AAA with value of $6, \mathrm{AA}+$ with value of 5 , etc. ${ }^{2}$.

DisQuality means disclosure quality of corporate information. There are many ways to measure the disclosure quality: Botosan (1997) [12] measured it by categorizing and evaluating five aspects of voluntary disclosed information which are useful for investors to make decisions, including background information, historical information, the key non-financial information, forecasting information and management information. Kim and Verrecchia (2001) [13] built an information disclosure quality model by using the corporate bond yielding rate and

\footnotetext{
${ }^{1}$ We use Rating to represent bond rating. It has 5 grades of AAA, AA+, AA, AA-, A+. Like credit, we assign AAA with value of 5 , AA+ with value of 4 , etc.

${ }^{2}$ In the robustness test, we also attempt to put AAA in the first category, put $\mathrm{AA}+, \mathrm{AA}, \mathrm{AA}-$ in the second category, put $\mathrm{A}+$, $\mathrm{A}$ in the third category.
} 
trading volume, this model can help avoid problems caused by corporate earnings manipulation. Francis et al. (2003) [14] used the listed companies' accounting earnings quality to evaluate the quality of information disclosure. Chinese researchers mostly use the information disclosure quality evaluation results published by Shenzhen Stock Exchange since 2001 (Zeng et al., 2006; Wang et al., 2008) [15] [16]. The Shenzhen Stock Exchange's evaluation results have 4 grades ${ }^{3}$, which are "excellent", "good", "qualified" and "fail” (in some years also represented as ABCD). The main content of the Shenzhen Stock Exchange evaluation includes: 1) The authenticity, accuracy, completeness, timeliness, legal compliance and fairness of the information disclosure of listed companies; 2) Penalties, sanctions and other regulatory measures for listed companies case; 3) Listed companies' willing to cooperate with the Shenzhen Stock Exchange; 4) Management of the listed companies' information disclosure affairs; 5) Other situations defined by Shenzhen Stock Exchange. As the Shenzhen Stock Exchange's data is quite reliable, we also use it to proxy the disclosure quality. On the other hand, considering the Shenzhen Stock Exchange's data is simply divided into four levels, it does not distinguish between voluntary disclosure and mandatory disclosure, and the evaluation index system is also not announced. More importantly, the data doesn't cover companies listed on the Shanghai Stock Exchange, so there might be some problems. In order to make the results more robust, we also use the Chinese listed companies information disclosure index (Gao Minghua, Beijing Normal University, 2010, 2012) [17] [18] as the indicator in the robustness test. Gao's index measured the integrity of the information disclosure (including mandatory and voluntary), although it only has two years data, it covered more listed companies.

According to existing research results, we choose accounting information quality, basic business financial condition, macroeconomic, corporate nature and bond characteristic as control variables of our model.

AccQuality is the variable for the accounting information quality. De Angelo (1981) [19] found a positive correlation between the audit agency's size and audit quality, as small audit agencies often fail to maintain their independence. Ball and Shivakumar (2005) [20], Zhang (2008) [21] used accounting conservatism to measure the accounting information quality. Earnings volatility is also commonly used to measure the quality of accounting information. Schipper and Vincent's (2003) [22] study shows that the volatility of corporate earnings will affect the quality of accounting information. Therefore, according to previous studies, we use audit quality, accounting conservatism and earnings volatility to characterize the quality of accounting information. Big4 (audit quality) is a dummy variable, equals 1 when the company accepts the "Big4" audit. Conserv (accounting conservatism) is calculated based on the cumulative accruals, the higher cumulative accruals, the lower conservatism, the lower accounting information quality. VarRoe (earnings volatility) is measured by the past three years Roe variance, the greater the variance, the greater the earnings volatility, the lower the accounting information quality.

Credit rating can be largely influenced by the corporate financial condition, so we control some relevant micro-financial variables in the model. Roe is return on equity, equals net profit/average shareholders' equity. CFO is corporate cash flow, equals operating cash flow/total assets. Lev is the asset-liability ratio, equals total liabilities/total assets. Size is the size of scale, equals to the natural logarithm of total assets. Some studies show that domestic macroeconomic development will have a significant impact on the corporate credit rating. Therefore, this article controls the macro-economic factor GDPgrow which is the real GDP growth of the year. In addition, for examining the differences between SOEs and non-SOEs, we use the State variable, a dummy variable that equals 1 when the company is state owned.

Some bond features ${ }^{4}$ such as bond duration and guarantee will also affect the credit risk; we use Duration and Guarantee variables. Guarantee is a dummy variable which equals 1 if there's guarantee. This article includes a sample of short-term financing bonds, medium-term notes, enterprise bonds and corporate bonds. Type is the bond type dummy variables (including Type S, Type M, Type E, Type C), Type S equals 1 means it is shortterm financing bonds; TypeM equals 1 means it is medium-term notes; Type $\mathrm{E}$ equals 1 means it is enterprise bonds; Type $\mathrm{C}$ equals 1 means it is corporate bonds. In order to reduce the endogenous problem between the dependent and independent variables, the independent variables in this article will all use the previous year data of the bond issuing.

With bond interest rates issued at different times can be affected by economic environment of that time, and the rates also diversify from bond duration due to liquidity difference. Therefore, drawing Zhang (2008) [21]

\footnotetext{
${ }^{3}$ In fact, there's no fail in the Shenzhen Stock Exchange's data, so we divided it into three levels, namely, excellent, good and qualified.

${ }^{4}$ These Control variables are used only when the dependent variable is Rating.
} 
and Wittenberg-Moerman's (2008) [23] measurement of debt financing cost, our model ${ }^{5}$ to test Hypotheses 2 is as follows:

$$
\begin{aligned}
\text { Spread }= & b_{0}+b_{1} \text { Credit }+b_{2} \text { DisQuality }+b_{3} \text { AccQuality }+b_{4} \text { Roe }+b_{5} \text { Size }+b_{6} \text { Lev }+b_{7} \text { CFO } \\
& +b_{8} \text { GDPgrow }+b_{9} \text { State }+b_{10} \text { Duration }+b_{11} \text { Guarantee }+b_{12} \text { Type }+\sum b_{i} \text { Inds } s_{i}+\varepsilon
\end{aligned}
$$

Spread means bond financing cost, calculated by the bond interest rate minus the bank lending rate of the same period. The same period means the same time and same duration. Other variables are the same with previous.

\subsection{Sample Selection}

Bond-related data in this article comes from the Wind financial terminal database, the time period is from 2007 to 2013, including short-term financing bonds, medium-term notes, enterprise bonds, corporate bonds. Due to the current data is based on the listed companies; we eliminate the non-listed companies from the bond-related data $^{6}$. The GDP data is collected from the China Statistical Yearbook, the bank lending and deposit rates are collected from the People's Bank of China website. We also eliminate the sample from financial sector. We winsorized all the continuous financial data at $1 \%$ level to avoid outliers. The sample selection process is shown in the Table 1.

\section{Empirical Results}

\subsection{Descriptive Statistics}

Table 2 shows the descriptive statistics ${ }^{7}$. Quality of information disclosure's (DisSz, Shenzhen Stock Exchange score) mean is 3.0932, median is 3 , the minimum value is 2 , indicating information disclosure quality of listed companies which issued bonds in the bond market is higher than the overall average. The interest rate spread's (Spread) mean is -0.3215 , median is -0.5 , showing bond financing cost is lower than bank loan. The mean of bond issuing corporate credit rating (Credit) is 3.9492, and the median is 4, showing the average credit rating in the sample is AA. Rating is the bond rating (due to various rating standards, this data does not include short-term bond), its mean is 3.4358, median is 3, indicating the average bond rating is AA.

AccQuality is characterized by three variables: Big 4, Conserv, VarRoe. We noticed only $11.30 \%$ companies in the sample choose Big 4 to do the financial report audit. Conserv has a mean with 0.0420 and median with -0.0152 , which means the reports are robust in general, but the 0.2601 deviation shows huge differences among companies. VarRoe, earnings volatility, is relatively small; its standard deviation also shows big differences. We can also see big difference among samples in Roe, Size, Lev, CFO, CR, QR, and LLR. About the company type, the $48.02 \%$ of the samples were state-owned. From the bond features, $23.73 \%$ of the sample has guarantee. The average bond duration is 3.9442 years, the median is 0.4932 , and standard deviation is 2.2444 , which shows huge differences in bond durations.

Table 3 and Figure 1 show the average information disclosure quality and spread in different corporate credit rating grades. As the quality data is collected from the previous year of the rating year, we can see the higher information disclosure quality, the higher corporate credit rating, which is in line with the Hypothesis 1.

\section{Table 1. Sample selection process.}

\begin{tabular}{cc}
\hline Listed Companies in Shenzhen Stock Exchange’s (2006-2012) & 6846 \\
\hline Match with the bond-related data (issued bond from 2007-2013) & 359 \\
Eliminating the sample from financial sector & 5 \\
Final sample & 354 \\
\hline
\end{tabular}

${ }^{5}$ Control variables in model (2) is basically the same with model (1), the nuances will be marked in the results.

${ }^{6}$ The selected sample is different after using the Shenzhen Stock Exchange's data and Gao's Chinese listed companies information disclosure index (2010, 2012) [17] [18] respectively. The Shenzhen Stock Exchange's data covers a longer time but only the companies listed in Shenzhen. Gao's index has only two years data, but it covers all A-share listed companies.

${ }^{7}$ All the continuous financial data has been winsorized at $1 \%$ level. 
Table 2. Descriptive statistics.

\begin{tabular}{ccccccc}
\hline Variable & Sample & Mean & $\begin{array}{c}\text { Standard } \\
\text { Deviation }\end{array}$ & Median & Minimum & Maximum \\
\hline DisSz & 354 & 3.0932 & 0.5320 & 3.0000 & 2.0000 & 4.0000 \\
Spread & 351 & -0.3215 & 1.0389 & -0.5000 & -2.5800 & 3.3400 \\
Credit & 354 & 3.9492 & 1.0308 & 4.0000 & 1.0000 & 6.0000 \\
Rating & 257 & 3.4358 & 0.8551 & 3.0000 & 1.0000 & 5.0000 \\
Big4 & 354 & 0.1130 & 0.3170 & 0.0000 & 0.0000 & 1.0000 \\
Conserv & 354 & 0.0420 & 0.2601 & -0.0152 & -0.4852 & 1.0425 \\
VarRoe & 354 & 0.0027 & 0.0042 & 0.0009 & 0.0000 & 0.0265 \\
Roe & 354 & 0.1040 & 0.0762 & 0.0926 & -0.0854 & 0.3850 \\
Size & 354 & 22.6768 & 1.1434 & 22.5090 & 20.6730 & 25.3587 \\
Lev & 354 & 0.5032 & 0.1556 & 0.5111 & 0.1340 & 0.8058 \\
CFO & 354 & 0.0405 & 0.0752 & 0.0371 & -0.1827 & 0.2734 \\
CR & 354 & 1.4915 & 1.0339 & 1.2523 & 0.2949 & 6.7566 \\
QR & 354 & 1.0895 & 0.8610 & 0.8668 & 0.1984 & 5.6689 \\
LLR & 354 & 17.6434 & 18.4839 & 11.6301 & 0.0000 & 73.0281 \\
GDPgrow & 354 & 8.1444 & 0.9286 & 7.7000 & 7.7000 & 14.2000 \\
State & 354 & 0.4802 & 0.5003 & 0.0000 & 0.0000 & 1.0000 \\
Duration & 354 & 3.9442 & 2.2444 & 5.0000 & 0.4932 & 10.0000 \\
Guarantee & 354 & 0.2373 & 0.4260 & 0.0000 & 0.0000 & 1.0000 \\
\hline
\end{tabular}

Table 3. Average information disclosure quality and spreadin different corporate credit rating grades.

\begin{tabular}{cccc}
\hline Credit & DisSz & Spread \\
\hline $1(\mathrm{~A})$ & 2.0000 & 0.4518 \\
$2(\mathrm{~A}+)$ & 3.1071 & 0.3893 \\
$3(\mathrm{AA}-)$ & 3.0667 & -0.3798 \\
$4(\mathrm{AA})$ & 2.9940 & -0.9404 \\
$5(\mathrm{AA}+)$ & 3.2885 & -1.4006 \\
$6(\mathrm{AAA})$ & 3.3750 & \\
\hline
\end{tabular}

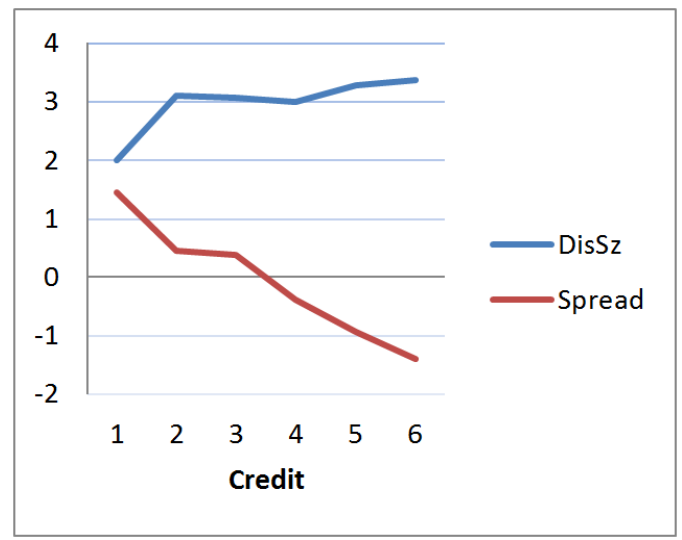

Figure 1. Average information disclosure quality and spread in different corporate credit rating grades.

With the increase of the corporate credit rating, the spread becomes lower, indicating the higher information disclosure quality, the lower bond financial cost, which supports the Hypothesis 2. In order to verify the results from multiple angles, the article also examines the average information disclosure quality and spread in different bond credit rating grades, as shown in Table 4 and Figure 2. The results are the same. 


\subsection{Regression Analysis}

\subsubsection{Credit Rating and Information Disclosure Quality}

As the corporate credit rating is based on the corporate's financial condition and macroeconomic environment, and previous research shows that corporate credit rating is also affected by the quality of accounting information. We controlled accounting information quality variables (Big4, Conserv, VarRoe), corporate basic variables (Roe, Size, Lev, CFO, CR, LLR, State), macroeconomic variable (GDPgrow), bond characteristic variables (Duration, Guarantee, Type) and industry, the regression results are shown in Table 5.

Model 1 uses Credit as the dependent variable, so we eliminate variables that are related to bond characteristics (Rating) such as Duration, Guarantee and Type. Model 2 uses Rating as the dependent variable, it's sample is smaller because it doesn't include the short-term financing bonds.

From Model 1's result, we can see the coefficients of Roe and Size $(7.206,2.725)$ are significantly positive at $1 \%$ level, indicating high profitability and big size can lead to high credit rating. The coefficient of Lev $(-8.192)$ is significantly negative at $1 \%$ level, showing high liability-asset ratio will bring low credit rating. All these prove that the signal effect does exist in the China's bond market, corporate's financial condition will affect its credit rating. The coefficient of GDPgrow $(-0.455)$ is significantly negative at $1 \%$ level, indicating the credit rating agencies tend to give higher credit rating at the time of macroeconomic recession, known as the "countercyclical" phenomenon, which is consistent with previous studies. The State's coefficient is 0.935 and significantly positive, indicating state-owned corporate gets a higher credit rating. The coefficients of accounting information quality variables (Big4, Conserv and VarRoe) are not significant, indicating credit rating agencies are not concerned about the accounting information quality, this collides with previous studies. The coefficient of DisSz is not significant, indicating the information disclosure quality doesn't has significant impact on the corporate credit rating, and this doesn't support Hypothesis 1. There might be 2 explanations: One is DisSz may not be a proper indicator; the other is as credit rating agencies often collect information from various kinds of channels, they don't pay much attention on the corporate's information disclosure quality. We'll find out in the robustness test. Model 2's result is almost the same with Model 1, except it has more variables. However, Model 2 also doesn't support Hypothesis 1.

Table 4. Average information disclosure quality and spreadin different corporate credit rating grades.

\begin{tabular}{ccc}
\hline Rating & DisSz & Spread \\
\hline $1(\mathrm{~A}+)$ & 3.0000 & 2.3500 \\
$2\left(\mathrm{AA}^{-}\right)$ & 3.0500 & 1.2856 \\
$3(\mathrm{AA})$ & 2.9645 & -0.0657 \\
$4(\mathrm{AA}+)$ & 3.1429 & -0.6732 \\
$5(\mathrm{AAA})$ & 3.4359 & -1.4059 \\
\hline
\end{tabular}

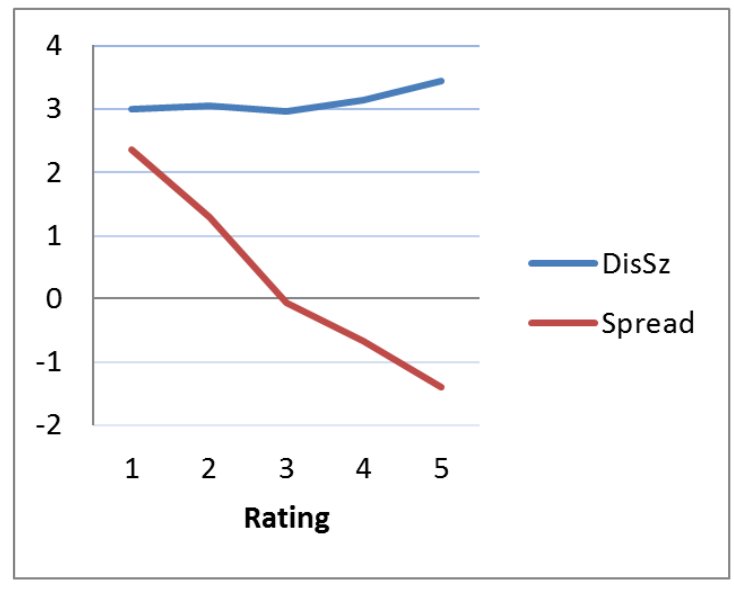

Figure 2. Average information disclosure quality and spread in different corporate credit rating grades. 
Table 5. The regression results of credit rating and information disclosure quality.

\begin{tabular}{|c|c|c|}
\hline \multirow{2}{*}{ Variable } & Model 1 & Model 2 \\
\hline & Credit & Rating \\
\hline \multirow[t]{2}{*}{ DisSz } & -0.0745 & 0.135 \\
\hline & $(-0.32)$ & $(0.46)$ \\
\hline \multirow[t]{2}{*}{ Big4 } & 0.615 & 0.605 \\
\hline & (1.45) & (1.21) \\
\hline \multirow[t]{2}{*}{ Conserv } & -0.991 & -0.232 \\
\hline & $(-1.53)$ & $(-0.27)$ \\
\hline \multirow[t]{2}{*}{ VarRoe } & $48.80^{*}$ & -36.61 \\
\hline & (1.64) & $(-0.94)$ \\
\hline \multirow[t]{2}{*}{ Roe } & $7.206^{* * *}$ & $5.411^{* *}$ \\
\hline & (3.85) & (2.30) \\
\hline \multirow[t]{2}{*}{ Size } & $2.725^{* * *}$ & $2.280^{* * * *}$ \\
\hline & (12.36) & (8.77) \\
\hline \multirow[t]{2}{*}{ Lev } & $-8.192^{* * *}$ & $-7.271^{* * *}$ \\
\hline & $(-5.68)$ & $(-3.96)$ \\
\hline \multirow[t]{2}{*}{ CFO } & 0.555 & -3.852 \\
\hline & $(0.26)$ & $(-1.39)$ \\
\hline \multirow[t]{2}{*}{ CR } & 0.125 & 0.0566 \\
\hline & $(0.68)$ & $(0.26)$ \\
\hline \multirow[t]{2}{*}{ LLR } & 0.0118 & 0.0119 \\
\hline & (1.44) & (1.16) \\
\hline \multirow[t]{2}{*}{ GDPgrow } & $-0.455^{* * *}$ & -0.0235 \\
\hline & $(-3.31)$ & $(-0.12)$ \\
\hline \multirow[t]{2}{*}{ State } & $0.935^{* * *}$ & $0.947^{* *}$ \\
\hline & (3.06) & (2.34) \\
\hline \multirow[t]{2}{*}{ Duration } & & -0.0190 \\
\hline & & $(-0.14)$ \\
\hline \multirow[t]{2}{*}{ Guarantee } & & $1.849^{* * *}$ \\
\hline & & (4.49) \\
\hline \multirow[t]{2}{*}{ Type C } & & -17.99 \\
\hline & & $(-0.02)$ \\
\hline \multirow[t]{2}{*}{ Type M } & & -19.74 \\
\hline & & $(-0.02)$ \\
\hline Inds & Control & Control \\
\hline$N$ & 354 & 257 \\
\hline$R^{2}$ & 0.395 & 0.434 \\
\hline
\end{tabular}

Note: ${ }^{* * *},{ }^{* *}$, and ${ }^{*}$ denote statistical significance at the 1,5 , and 10 percent levels, respectively.

\subsubsection{Bond Investors and Information Disclosure Quality}

As shown in Table 6, Model 3 examines whether information disclosure quality (DisSz) will significantly affect the bond spread without controlling the corporate credit rating (Credit) or bond rating (Rating). The regression shows that DisSz and Spread are significantly negatively correlated at 5\% level (P value equals 0.047 ), indicating the higher information disclosure quality, the lower bond financing cost, the results support the Hypothesis 2. Big4 and Spread are significantly negatively correlated at 5\% level, which means corporate audited by Big 4 has 
lower bond financing cost. VarRoe and Spread have a significant positive correlation at $5 \%$ level, indicating corporate with high earnings volatility has higher bond financing cost. The coefficient of Conserv is not significant, suggesting that bond investors may not be concerned about corporate accounting conservatism, which is inconsistent with previous findings. Among the financial condition variables, the coefficients of Lev, CFO, CR and LLR are not significant, indicating that investors are not concerned about this information. However the coefficient of Size is significantly negative at $1 \%$ level, indicating that the corporate with big size tends to have low bond financing cost. The coefficient of Roe is significantly negative at $5 \%$ level, indicating corporate with higher Roe has lower bond financing cost. In Model 5, we also find that GDPgrow has a significant positive correlation with Spread at $1 \%$ level, showing that although the central bank adjusts the benchmark interest along with the macroeconomic fluctuations, the bond financing cost is still affected by the fluctuations: in the year with high GDP growth rate, the bond financing cost is also high. The State coefficient shows that state-owned corporates have lower bond financing cost. The bond characteristics variables (Duration, Guarantee) are not significant, but the Type $\mathrm{C}$ and Type $\mathrm{M}$ are significantly positive at $1 \%$ level, indicating medium-term bond has relatively high bond financing cost.

We controlled corporate credit rating (Credit) and bond rating (Rating) in Model 4 and Model 5, respectively. The coefficient of DisSz is significantly negative at $10 \%$ level in both models. The results support Hypothesis 2 again. But after controlled Credit and Rating, the significance of DisSz decreased, indicating Credit and/or Rating may have played an intermediary role between the information disclosure quality and bond financing cost. As Hypothesis 1 is not supported by our regression, we can't tell what kind of intermediary role Credit and/or Rating may have played. Further study might be needed.

\subsection{Robustness Test}

\subsubsection{Sample Selection Bias}

In our sample selection, we eliminated all the listed companies which didn’t issue bond. But whether a listed company issue bond or not might be influenced by many factors. So there might be some listed companies wanted to issue bond but didn't due to some reasons and this could lead estimated results bias (Heckman, 1979) [24].

In order to overcome this sample selection bias, we use the Heckman (1979) [24] two-stage method to solve this problem. Table 7 is the regression results of the Heckman two-stage method. In the regression results, both coefficients of IMR are significant, indicating that we have bias in our sample selection. But after we controlled the sample selection bias, the results remained the same.

\subsubsection{Selection of the Information Disclosure Quality Indicator}

Considering the Shenzhen Stock Exchange's data is simply divided into four levels, it does not distinguish between voluntary disclosure and mandatory disclosure, and the evaluation index system is also not announced. More importantly, the data doesn't cover companies listed on the Shanghai Stock Exchange, so there might be some problem. In order to make the results more robust, we use the Chinese listed companies information disclosure index (Gao Minghua, Beijing Normal University, 2010, 2012) [17] [18] as the indicator to do another test. CCDI measures the integrity of the information disclosure (including mandatory and voluntary), although it only has 2 years data, but it covered more listed companies. The main indicator definitions of CCDI are shown in Table 8.

The sample selection and elimination process is similar: eliminated all the financial sector data and winsorized at $1 \%$ level, as shown in Table 9.

As for Hypothesis 1, we use CCDI and 4 secondary indicators to replace DisSz, other variables remain the same. The regression results are shown in Table $10^{8}$.

From Table 10 we can see that the coefficient of CCDI in Model 6 and Model 8 are insignificant, and almost all of the coefficients of the 4 secondary indicators are insignificant. The results also do not support Hypothesis 1. As China's bond market is not efficient, there always exist inside information that cannot be reflected in the public disclosed information. So credit rating agencies tend to have a lot of channels to access inside information, information disclosure quality is hard to attract enough attention.

As for Hypothesis 2, we also use CCDI and 4 secondary indicators to replace DisSz, other variables remain the same. Results are shown in Table 11.

\footnotetext{
${ }^{8}$ We also used Heckman two-stage method. Results showed there is no bias in CCDI sample selection. Results are not reported in this article.
} 
Table 6. The regression results of bond financing cost and information disclosure quality.

\begin{tabular}{|c|c|c|c|}
\hline \multirow{2}{*}{ Variable } & Model 3 & Model 4 & Model 5 \\
\hline & Spread & Spread & Spread \\
\hline \multirow[t]{2}{*}{ Credit } & & $-0.616^{* * *}$ & \\
\hline & & $(-7.41)$ & \\
\hline \multirow[t]{2}{*}{ Rating } & & & $-0.623^{* * *}$ \\
\hline & & & $(-6.97)$ \\
\hline \multirow[t]{2}{*}{ DisSz } & $-0.180^{* *}$ & $-0.164^{*}$ & $-0.150^{*}$ \\
\hline & $(-1.99)$ & $(-1.97)$ & $(-1.65)$ \\
\hline \multirow[t]{2}{*}{ Big4 } & $-0.349^{* *}$ & $-0.333^{* *}$ & $-0.285^{*}$ \\
\hline & $(-2.12)$ & $(-2.19)$ & $(-1.82)$ \\
\hline \multirow[t]{2}{*}{ Conserv } & 0.298 & 0.245 & 0.400 \\
\hline & (1.18) & (1.05) & (1.58) \\
\hline \multirow[t]{2}{*}{ VarRoe } & $24.44^{* *}$ & $29.23^{* * *}$ & $32.15^{* * *}$ \\
\hline & (2.15) & $(2.77)$ & $(2.86)$ \\
\hline \multirow[t]{2}{*}{ Roe } & $-1.581^{* *}$ & -0.868 & -0.706 \\
\hline & $(-2.20)$ & $(-1.29)$ & $(-1.00)$ \\
\hline \multirow[t]{2}{*}{ Size } & $-0.351^{* * *}$ & 0.126 & -0.0426 \\
\hline & $(-5.89)$ & (1.48) & $(-0.55)$ \\
\hline \multirow[t]{2}{*}{ Lev } & 0.778 & -0.625 & -0.319 \\
\hline & (1.47) & $(-1.19)$ & $(-0.56)$ \\
\hline \multirow[t]{2}{*}{ CFO } & -0.217 & -0.0721 & -0.0629 \\
\hline & $(-0.26)$ & $(-0.09)$ & $(-0.08)$ \\
\hline \multirow[t]{2}{*}{ CR } & -0.0811 & -0.0952 & -0.0859 \\
\hline & $(-1.17)$ & $(-1.49)$ & $(-1.29)$ \\
\hline \multirow[t]{2}{*}{ LLR } & -0.00103 & 0.000980 & 0.00230 \\
\hline & $(-0.32)$ & $(0.33)$ & $(0.75)$ \\
\hline \multirow[t]{2}{*}{ GDPgrow } & $0.186^{* * *}$ & $0.130^{* *}$ & $0.154^{* *}$ \\
\hline & $(2.72)$ & $(2.04)$ & $(2.58)$ \\
\hline \multirow[t]{2}{*}{ State } & $-0.461^{* * *}$ & $-0.323^{* * * *}$ & $-0.274^{* *}$ \\
\hline & $(-3.81)$ & $(-2.85)$ & $(-2.21)$ \\
\hline \multirow[t]{2}{*}{ Duration } & -0.0652 & -0.0644 & -0.0615 \\
\hline & $(-1.46)$ & $(-1.55)$ & $(-1.56)$ \\
\hline \multirow[t]{2}{*}{ Guarantee } & -0.147 & $-0.261^{* *}$ & 0.165 \\
\hline & $(-1.13)$ & $(-2.16)$ & $(1.37)$ \\
\hline \multirow[t]{2}{*}{ Type S } & $1.181^{*}$ & $1.453^{* *}$ & \\
\hline & (1.87) & $(2.48)$ & \\
\hline \multirow[t]{2}{*}{ Type C } & $1.708^{* * *}$ & $2.499^{* * *}$ & $0.325^{* *}$ \\
\hline & (3.12) & $(4.83)$ & $(2.30)$ \\
\hline \multirow[t]{2}{*}{ Type E } & & & -0.699 \\
\hline & & & $(-1.37)$ \\
\hline \multirow[t]{2}{*}{ Type M } & $1.601^{* * *}$ & $2.057^{* * *}$ & \\
\hline & $(2.82)$ & (3.89) & \\
\hline Inds & Control & Control & Control \\
\hline$N$ & 351 & 351 & 255 \\
\hline$R^{2}$ & 0.427 & 0.510 & 0.583 \\
\hline
\end{tabular}

Note: ${ }^{* * *}, * *$ and ${ }^{*}$ denote statistical significance at the 1,5 , and 10 percent levels, respectively. 
Table 7. Heckman two-stage method regression analysis.

\begin{tabular}{|c|c|c|c|c|}
\hline & & Credit & & Rating \\
\hline \multirow[t]{2}{*}{ IMR } & & $0.644^{*}$ & & $1.417^{* *}$ \\
\hline & & (1.66) & & $(2.52)$ \\
\hline \multirow[t]{2}{*}{ DisSz } & -0.0476 & -0.0560 & -0.0912 & -0.0225 \\
\hline & $(-0.84)$ & $(-0.77)$ & $(-1.50)$ & $(-0.19)$ \\
\hline \multirow[t]{2}{*}{ Big4 } & 0.00580 & 0.157 & 0.0580 & 0.160 \\
\hline & $(0.05)$ & (1.19) & $(0.43)$ & $(0.77)$ \\
\hline \multirow[t]{2}{*}{ Conserv } & 0.101 & -0.0936 & 0.00276 & 0.0462 \\
\hline & $(0.61)$ & $(-0.48)$ & $(0.02)$ & $(0.15)$ \\
\hline \multirow[t]{2}{*}{ VarRoe } & $-24.98^{* * *}$ & -2.524 & $-20.57^{* * *}$ & $-27.57^{* *}$ \\
\hline & $(-4.51)$ & $(-0.24)$ & $(-3.69)$ & $(-2.07)$ \\
\hline \multirow[t]{2}{*}{ Roe } & -0.437 & $1.770^{* * *}$ & 0.110 & $1.721^{* *}$ \\
\hline & $(-0.91)$ & (3.32) & $(0.22)$ & (2.03) \\
\hline \multirow[t]{2}{*}{ Size } & $0.567^{* * * *}$ & $1.054^{* * * *}$ & $0.543^{* * * *}$ & $1.069^{* * *}$ \\
\hline & (13.96) & (6.09) & (12.42) & $(4.20)$ \\
\hline \multirow[t]{2}{*}{ Lev } & $-1.064^{* * *}$ & $-2.837^{* * *}$ & $-1.027^{* * *}$ & $-3.536^{* * *}$ \\
\hline & $(-3.23)$ & $(-4.75)$ & $(-2.90)$ & $(-3.97)$ \\
\hline \multirow[t]{2}{*}{ CFO } & -0.822 & -0.182 & $-1.086^{*}$ & $-2.670^{* *}$ \\
\hline & $(-1.52)$ & $(-0.27)$ & $(-1.87)$ & $(-2.51)$ \\
\hline \multirow[t]{2}{*}{ CR } & $-0.230^{* * *}$ & -0.0632 & $-0.176^{* * *}$ & $-0.250^{* *}$ \\
\hline & $(-5.90)$ & $(-0.69)$ & $(-4.60)$ & $(-2.25)$ \\
\hline \multirow[t]{2}{*}{ LLR } & 0.00178 & 0.00207 & 0.00245 & 0.00671 \\
\hline & $(0.78)$ & $(0.76)$ & $(1.02)$ & (1.59) \\
\hline \multirow[t]{2}{*}{ GDPgrow } & $-0.330^{* * *}$ & $-0.299^{* * *}$ & $-0.240^{* * *}$ & -0.194 \\
\hline & $(-9.70)$ & $(-2.74)$ & $(-7.21)$ & $(-1.57)$ \\
\hline \multirow[t]{2}{*}{ State } & $-0.296^{* * *}$ & 0.198 & $-0.214^{* *}$ & 0.124 \\
\hline & $(-3.79)$ & $(1.52)$ & $(-2.54)$ & $(0.71)$ \\
\hline Inds & Control & Control & Control & Control \\
\hline \multirow[t]{2}{*}{ PR } & $0.0125^{* * *}$ & & $0.0115^{* * *}$ & \\
\hline & (3.10) & & (2.68) & \\
\hline \multirow[t]{2}{*}{ Top1 } & $-0.00442^{* *}$ & & $-0.00548^{* *}$ & \\
\hline & $(-2.09)$ & & $(-2.39)$ & \\
\hline$N$ & 6594 & & 6497 & \\
\hline
\end{tabular}

Note: ${ }^{* * * * *}$, and ${ }^{*}$ denote statistical significance at the 1,5 , and 10 percent levels, respectively.

\section{Table 8. CCDI ${ }^{\mathrm{a}}$ main indicator definition.}

\begin{tabular}{|c|c|}
\hline Indicator & Definition \\
\hline Inte_Enfor & $\begin{array}{l}\text { Mandatory disclosed information, regulated by Securities Act, Accounting Standards and other regulatory } \\
\text { authorities, including corporate governance guidelines, ownership structure, board of directors, supervisors and } \\
\text { executives, key financial indicators, etc. }\end{array}$ \\
\hline Inte_Volun & $\begin{array}{l}\text { Voluntary disclosed information, voluntarily provided by the management of listed companies, including the } \\
\text { composition of the board of directors (excluding managers) and supervisors, stakeholders, financial and risk } \\
\text { analysis, etc. }\end{array}$ \\
\hline Truth & $\begin{array}{l}\text { Authenticity of disclosed information, including board of directors' responsibility statement, board of supervisors' } \\
\text { responsibility statement, violation investigation, whether the auditor has retained opinions. }\end{array}$ \\
\hline Time & Timeliness of information disclosure, such as financial report. \\
\hline
\end{tabular}
Inte_enfor 0.096 . 
Table 9. Sample selection process of CCDI.

\begin{tabular}{cc}
\hline Listed companies in CCDI data in 2009 and 2010 & 3662 \\
\hline Match with listed companies issued bond in 2010 and 2012 & 278 \\
\hline
\end{tabular}

Table 10. The regression results of credit ratings and CCDI.

\begin{tabular}{|c|c|c|c|c|}
\hline & Model 6 & Model 7 & Model 8 & Model 9 \\
\hline & Credit & Credit & Rating & Rating \\
\hline \multirow[t]{2}{*}{ CCDI } & -0.0148 & & -0.00600 & \\
\hline & $(-1.28)$ & & $(-0.49)$ & \\
\hline \multirow{2}{*}{ Inte_Enfor } & & -0.00159 & & -0.00160 \\
\hline & & $(-0.29)$ & & $(-0.28)$ \\
\hline \multirow[t]{2}{*}{ Inte_Volun } & & $-0.0110^{* *}$ & & -0.00472 \\
\hline & & $(-2.01)$ & & $(-0.86)$ \\
\hline \multirow[t]{2}{*}{ Truth } & & 0.00526 & & 0.00888 \\
\hline & & $(0.44)$ & & $(0.66)$ \\
\hline \multirow[t]{2}{*}{ Time } & & -0.000551 & & -0.00127 \\
\hline & & $(-0.15)$ & & $(-0.34)$ \\
\hline \multirow[t]{2}{*}{ Big4 } & 0.147 & 0.138 & 0.0867 & 0.0858 \\
\hline & $(1.33)$ & (1.24) & $(0.77)$ & $(0.75)$ \\
\hline \multirow[t]{2}{*}{ Conserv } & -0.0159 & 0.0450 & -0.0722 & -0.0297 \\
\hline & $(-0.08)$ & $(0.21)$ & $(-0.34)$ & $(-0.14)$ \\
\hline \multirow[t]{2}{*}{ VarRoe } & 0.426 & 0.473 & $6.895^{* *}$ & $6.788^{* *}$ \\
\hline & $(0.14)$ & $(0.15)$ & (2.29) & $(2.23)$ \\
\hline \multirow[t]{2}{*}{ Roe } & $1.467^{* * *}$ & $1.330^{* *}$ & 0.250 & 0.235 \\
\hline & (2.89) & (2.58) & $(0.48)$ & $(0.44)$ \\
\hline \multirow[t]{2}{*}{ Size } & $0.526^{* * *}$ & $0.540^{* * * *}$ & $0.406^{* * *}$ & $0.410^{* * *}$ \\
\hline & (13.64) & (13.40) & $(10.12)$ & $(9.76)$ \\
\hline \multirow[t]{2}{*}{ Lev } & $-1.231^{* * *}$ & $-1.281^{* * *}$ & $-0.778^{* *}$ & $-0.784^{* *}$ \\
\hline & $(-3.23)$ & $(-3.31)$ & $(-2.01)$ & $(-2.00)$ \\
\hline \multirow[t]{2}{*}{ CFO } & -0.760 & -0.752 & -1.004 & -0.980 \\
\hline & $(-1.06)$ & $(-1.05)$ & $(-1.38)$ & $(-1.34)$ \\
\hline \multirow[t]{2}{*}{ CR } & 0.0806 & 0.0765 & 0.0551 & 0.0505 \\
\hline & $(1.50)$ & $(1.41)$ & $(1.04)$ & $(0.94)$ \\
\hline \multirow[t]{2}{*}{ LLR } & 0.0032 & 0.0029 & 0.0004 & 0.0003 \\
\hline & $(1.26)$ & $(1.14)$ & $(0.14)$ & $(0.11)$ \\
\hline \multirow[t]{2}{*}{ GDPgrow } & $-0.149^{* * *}$ & $-0.145^{* *}$ & 0.00373 & 0.0280 \\
\hline & $(-2.73)$ & $(-2.29)$ & $(0.07)$ & $(0.41)$ \\
\hline \multirow[t]{2}{*}{ State } & $0.254^{* * *}$ & $0.234^{* * *}$ & $0.155^{*}$ & 0.144 \\
\hline & (2.94) & (2.64) & $(1.75)$ & (1.58) \\
\hline \multirow[t]{2}{*}{ Duration } & & & -0.0307 & -0.0308 \\
\hline & & & $(-1.38)$ & $(-1.38)$ \\
\hline \multirow[t]{2}{*}{ Guarantee } & & & $0.426^{* * *}$ & $0.422^{* * * *}$ \\
\hline & & & $(4.57)$ & $(4.49)$ \\
\hline \multirow[t]{2}{*}{ Type C } & & & $0.287^{* * * *}$ & $0.288^{* * * *}$ \\
\hline & & & (2.95) & (2.93) \\
\hline Inds & Control & Control & Control & Control \\
\hline$N$ & 273 & 273 & 253 & 253 \\
\hline$R^{2}$ & 0.746 & 0.749 & 0.695 & 0.696 \\
\hline
\end{tabular}

Note: ${ }^{* * *},{ }^{* *}$, and ${ }^{*}$ denote statistical significance at the 1,5 , and 10 percent levels, respectively. 
Table 11. The regression results of bond financing cost and CCDI.

\begin{tabular}{|c|c|c|c|c|c|c|}
\hline & Model 10 & Model 11 & Model 12 & Model 13 & Model 14 & Model 15 \\
\hline & Spread & Spread & Spread & Spread & Spread & Spread \\
\hline \multirow[t]{2}{*}{ CCDI } & 0.000176 & & -0.00345 & & -0.00630 & \\
\hline & $(0.01)$ & & $(-0.27)$ & & $(-0.45)$ & \\
\hline \multirow[t]{2}{*}{ Inte_Enfor } & & -0.00348 & & -0.00333 & & -0.00551 \\
\hline & & $(-0.52)$ & & $(-0.55)$ & & $(-0.84)$ \\
\hline \multirow[t]{2}{*}{ Inte_Volun } & & 0.00914 & & 0.00426 & & 0.00644 \\
\hline & & (1.39) & & $(0.71)$ & & (1.02) \\
\hline \multirow[t]{2}{*}{ Truth } & & -0.00372 & & -0.00159 & & -0.00168 \\
\hline & & $(-0.26)$ & & $(-0.12)$ & & $(-0.11)$ \\
\hline \multirow[t]{2}{*}{ Time } & & -0.00526 & & -0.00396 & & -0.00614 \\
\hline & & $(-1.18)$ & & $(-0.97)$ & & $(-1.43)$ \\
\hline \multirow[t]{2}{*}{ Credit } & & & $-0.539^{* * *}$ & $-0.529^{* * *}$ & & \\
\hline & & & $(-7.27)$ & $(-7.06)$ & & \\
\hline \multirow[t]{2}{*}{ Rating } & & & & & $-0.496^{* * *}$ & $-0.493^{* * *}$ \\
\hline & & & & & $(-6.32)$ & $(-6.29)$ \\
\hline \multirow[t]{2}{*}{ Big4 } & $-0.227^{*}$ & -0.209 & -0.172 & -0.162 & -0.196 & -0.184 \\
\hline & $(-1.69)$ & $(-1.55)$ & $(-1.41)$ & $(-1.32)$ & $(-1.49)$ & $(-1.40)$ \\
\hline \multirow[t]{2}{*}{ Conserv } & $0.675^{* * *}$ & $0.634^{* *}$ & $0.625^{* * *}$ & $0.611^{* *}$ & $0.636^{* * *}$ & $0.614^{* *}$ \\
\hline & (2.65) & $(2.43)$ & $(2.71)$ & (2.57) & (2.62) & $(2.47)$ \\
\hline \multirow[t]{2}{*}{ VarRoe } & 3.508 & 3.137 & 4.001 & 3.744 & $6.778^{*}$ & $6.366^{*}$ \\
\hline & $(0.94)$ & $(0.84)$ & (1.19) & (1.11) & (1.92) & $(1.80)$ \\
\hline \multirow[t]{2}{*}{ Roe } & $-1.918^{* * *}$ & $-1.736^{* * *}$ & $-1.242^{* *}$ & $-1.148^{* *}$ & $-1.766^{* * *}$ & $-1.577^{* *}$ \\
\hline & $(-3.07)$ & $(-2.75)$ & $(-2.17)$ & $(-1.98)$ & $(-2.93)$ & $(-2.59)$ \\
\hline \multirow[t]{2}{*}{ Size } & $-0.305^{* * *}$ & $-0.331^{* * *}$ & -0.00395 & -0.0258 & $-0.115^{* *}$ & $-0.141^{* *}$ \\
\hline & $(-6.47)$ & $(-6.72)$ & $(-0.07)$ & $(-0.41)$ & $(-2.05)$ & $(-2.42)$ \\
\hline \multirow[t]{2}{*}{ Lev } & $0.840^{*}$ & $0.955^{* *}$ & 0.248 & 0.335 & 0.477 & 0.582 \\
\hline & $(1.81)$ & (2.04) & $(0.58)$ & $(0.77)$ & (1.05) & (1.28) \\
\hline \multirow[t]{2}{*}{$\mathrm{CFO}$} & $1.796^{* *}$ & $1.829^{* *}$ & 1.163 & 1.203 & 1.252 & 1.303 \\
\hline & (2.03) & (2.07) & (1.45) & (1.49) & (1.48) & (1.54) \\
\hline \multirow[t]{2}{*}{ CR } & -0.0544 & -0.0538 & -0.00881 & -0.0104 & -0.0311 & -0.0345 \\
\hline & $(-0.84)$ & $(-0.83)$ & $(-0.15)$ & $(-0.18)$ & $(-0.51)$ & $(-0.56)$ \\
\hline \multirow[t]{2}{*}{ LLR } & -0.00500 & -0.00473 & -0.00392 & -0.00382 & -0.00447 & -0.00426 \\
\hline & $(-1.60)$ & $(-1.49)$ & $(-1.38)$ & $(-1.32)$ & $(-1.49)$ & $(-1.40)$ \\
\hline \multirow[t]{2}{*}{ GDPgrow } & 0.0226 & 0.0601 & -0.0301 & 0.000329 & 0.0163 & 0.0671 \\
\hline & $(0.33)$ & $(0.78)$ & $(-0.49)$ & $(0.00)$ & $(0.25)$ & $(0.85)$ \\
\hline \multirow[t]{2}{*}{ State } & $-0.382^{* * *}$ & $-0.355^{* * *}$ & $-0.234^{* *}$ & $-0.220^{* *}$ & $-0.302^{* * *}$ & $-0.278^{* * * *}$ \\
\hline & $(-3.58)$ & $(-3.25)$ & $(-2.37)$ & $(-2.18)$ & $(-2.94)$ & $(-2.65)$ \\
\hline \multirow[t]{2}{*}{ Duration } & 0.0249 & 0.0273 & 0.00845 & 0.0103 & 0.0149 & 0.0172 \\
\hline & $(0.92)$ & $(1.00)$ & $(0.34)$ & $(0.42)$ & $(0.58)$ & $(0.67)$ \\
\hline \multirow[t]{2}{*}{ Guarantee } & -0.111 & -0.122 & $-0.181^{*}$ & $-0.188^{*}$ & 0.0985 & 0.0828 \\
\hline & $(-0.97)$ & $(-1.06)$ & $(-1.74)$ & $(-1.79)$ & $(0.87)$ & $(0.73)$ \\
\hline \multirow[t]{2}{*}{ Type C } & 0.0574 & 0.0380 & $0.449^{* *}$ & $0.425^{* *}$ & & $0.319^{* * *}$ \\
\hline & $(0.27)$ & $(0.18)$ & (2.23) & (2.09) & & $(2.77)$ \\
\hline Type M & -0.133 & -0.137 & 0.0463 & 0.0361 & $-0.333^{* * *}$ & \\
\hline & $(-0.67)$ & $(-0.69)$ & $(0.25)$ & $(0.20)$ & $(-2.90)$ & \\
\hline Inds & Control & Control & Control & Control & Control & Control \\
\hline$N$ & 273 & 273 & 273 & 273 & 253 & 253 \\
\hline$R^{2}$ & 0.604 & 0.610 & 0.676 & 0.679 & 0.669 & 0.675 \\
\hline
\end{tabular}

Note: ${ }^{* * *},{ }^{* *}$, and ${ }^{*}$ denote statistical significance at the 1,5 , and 10 percent levels, respectively. 
All the coefficients of CCDI and 4 secondary indicators in Table 11 are insignificant. The results also do not support Hypothesis 2. But the coefficients of Credit and Rating are significant at $1 \%$ level, suggesting high corporate credit rating could reduce financing cost.

The regression results of CCDI partly supported the hypothesis of this paper, but there are some differences. The reason for this result might be that although investors are concerned about the quality of corporate information disclosure, usually they cannot assess the disclosure quality themselves, so they often use the authorities' evaluation result. Clearly, Shenzhen Stock Exchange data has much more influence than CCDI.

\section{Conclusion}

As a signal, information disclosure plays an important role in the capital market, although many studies supported the signal theory from the theoretical and empirical level, but researchers in China found only participants of the stock market are concerned about information disclosure quality. This article assumes signal theory also applied in China and participants of the bond market should be concerned about information disclosure quality. But our empirical results only support Hypothesis 2: investors and corporates who have issued bonds are concerned about information disclosure quality and credit rating agencies are not. The reason for this result may be that credit rating agencies have a lot of channels to access information and the disclosed information doesn't gain enough attention. The main contribution of this article is to make up for the lack of research of the information disclosure quality in China's bond market.

\section{Funding}

This paper is sponsored by the National Natural Science Fund (713022023), the Fundamental Research Funds for the Central Universities, Beijing Normal University (2012WYB35), and Beijing Higher Education Young Elite Program (YETP0298).

\section{References}

[1] Bottelier, P. (2003) China's Emerging Domestic Debt Markets: Facts and Issues. Discussion paper for a Conference on Chinese Economic Policy Reform, Stanford Center for International Development (SCID), 18-20 September 2003, 127.

[2] Barry, C. and Brown, S.J. (1985) Differential Information and Security Market Equilibrium. Journal of Financial and Quantitative Analysis, 20, 407-422. http://dx.doi.org/10.2307/2330758

[3] Coles, J.L. and Loewenstein, U. (1988) Equilibrium Pricing and Portfolio Composition in the Presence of Uncertain Parameters. Journal of Financial Economics, 22, 279-303. http://dx.doi.org/10.1016/0304-405X(88)90072-4

[4] Clarkson, P., Guedes, J. and Thompson, R. (1996) On the Diversification, Observability, and Measurement of Estimation risk. Journal of Financial and Quantitative Analysis, 31, 69-84. http://dx.doi.org/10.2307/2331387

[5] Heflin, F., Shaw, K.W. and Wild, J.J. (2011) Credit Ratings and Disclosure Channels. Research in Accounting Regulation, 23, 20-33. http://dx.doi.org/10.1016/j.racreg.2011.03.004

[6] Diamond, D.W. and Verrecchia, R.E. (1991) Disclosure, Liquidity, and the Cost of Capital. The journal of Finance, 46, 1325-1359. http://dx.doi.org/10.1111/j.1540-6261.1991.tb04620.x

[7] Handa, P. and Linn, S.C. (1993) Arbitrage Pricing with Estimation Risk. Journal of Financial and Quantitative Analysis, 28, 81-100. http://dx.doi.org/10.2307/2331152

[8] Zhu, S. (2013) Credit Rating in China's Bond Market: Evidence from Short-Term Financing Bonds. Modern Economy, 4, 119-129.

[9] Wiedman, C. (2000) Discussion of "Voluntary Disclosure and Equity Offerings: Reducing Information Asymmetry or Hyping the Stock?”. Contemporary Accounting Research, 17, 663-669. http://dx.doi.org/10.1506/DWU8-P832-UTX1-48AD

[10] Elton, E.J., Gruber, M.J., Agrawal, D., et al. (2004) Factors Affecting the Valuation of Corporate Bonds. Journal of Banking \& Finance, 28, 2747-2767. http://dx.doi.org/10.1016/j.jbankfin.2004.06.008

[11] Perraudin, W. and Taylor, A.P. (2004) On the Consistency of Ratings and Bond Market Yields. Journal of Banking \& Finance, 28, 2769-2788. http://dx.doi.org/10.1016/j.jbankfin.2004.06.009

[12] Botosan, C.A. (1997) Disclosure Level and the Cost of Equity Capital. Accounting Review, 72, 323-349.

[13] Kim, O. and Verrecchia, R.E. (2001) The Relation among Disclosure, Returns, and Trading Volume Information. Ac- 
counting Review, 76, 633-654. http://dx.doi.org/10.2308/accr.2001.76.4.633

[14] Francis, J., Khurana, I. and Pereira, R. (2003) Global Evidence on Incentives for Voluntary Accounting Disclosures and the Effect on Cost of Capital. College of Business Working Paper, University of Missouri at Columbia.

[15] Zeng, Y. and Lu, Z.F. (2006) Information Disclosure Quality and Equity Financing Cost. Economic Research, $2,2$.

[16] Wang, B. and Liang, X.X. (2008) Corporate Governance, Financial Condition and Quality of Information Disclosure: Evidence from the Shenzhen Stock Exchange. Accounting Research, 2, 31-39.

[17] Gao, M.H. (2010) Chinese Listed Companies Information Disclosure Index Report. Economic Science Press, Beijing.

[18] Gao, M.H. (2012) Chinese Listed Companies Information Disclosure Index Report. Economic Science Press, Beijing.

[19] Deangelo, L.E. (1981) Auditor Size and Audit Quality. Journal of Accounting and Economics, 3, $183-199$. http://dx.doi.org/10.1016/0165-4101(81)90002-1

[20] Ball, R. and Shivakumar, L. (2005) Earnings Quality in UK Private Firms: Comparative Loss Recognition Timeliness. Journal of Accounting and Economics, 39, 83-128. http://dx.doi.org/10.1016/j.jacceco.2004.04.001

[21] Zhang, J.Y. (2008) The Contracting Benefits of Accounting Conservatism to Lenders and Borrowers. Journal of Accounting and Economics, 45, 27-54. http://dx.doi.org/10.1016/j.jacceco.2007.06.002

[22] Schipper, K. and Vincent, L. (2003) Earnings Quality. Accounting Horizons, 17, 97-110.

[23] Wittenberg-Moerman, R. (2008) The Role of Information Asymmetry and Financial Reporting Quality in Debt Trading: Evidence from the Secondary Loan Market. Journal of Accounting and Economics, 46, 240-260. http://dx.doi.org/10.1016/j.jacceco.2008.08.001

[24] Heckman, J.J. (1979) Sample Selection Bias as a Specification Error. Econometrica, 47, 153-161. http://dx.doi.org/10.2307/1912352 
Scientific Research Publishing (SCIRP) is one of the largest Open Access journal publishers. It is currently publishing more than 200 open access, online, peer-reviewed journals covering a wide range of academic disciplines. SCIRP serves the worldwide academic communities and contributes to the progress and application of science with its publication.

Other selected journals from SCIRP are listed as below. Submit your manuscript to us via either submit@scirp.org or Online Submission Portal.
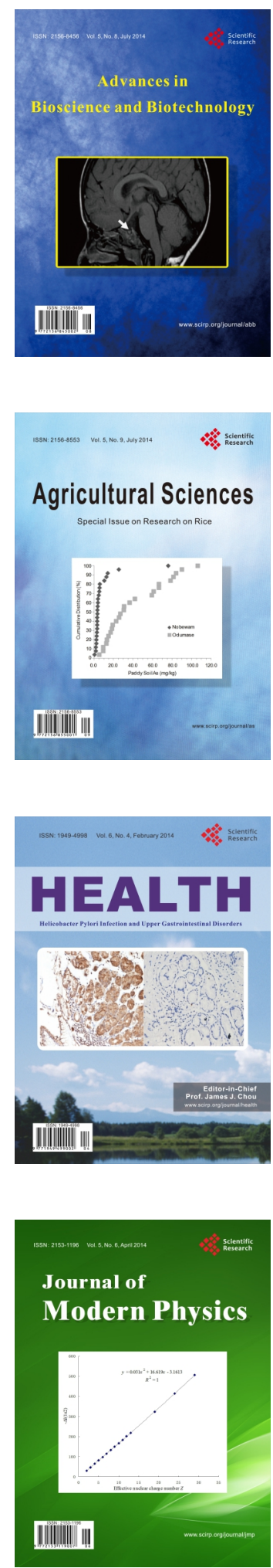
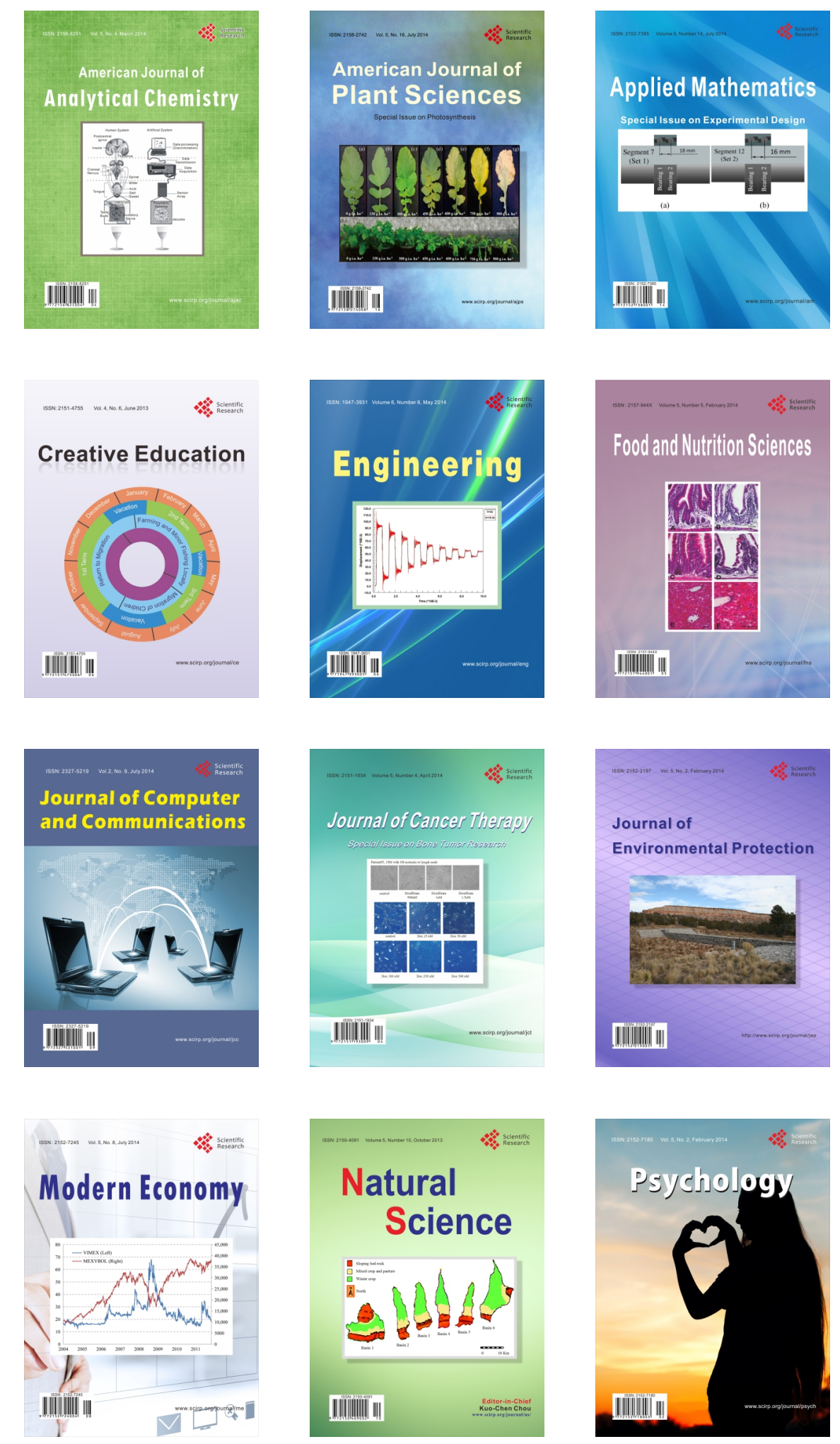